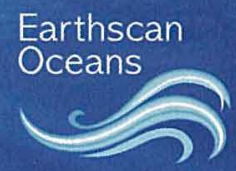

\title{
The
}

\section{Great Barrier Reef} An environmental history

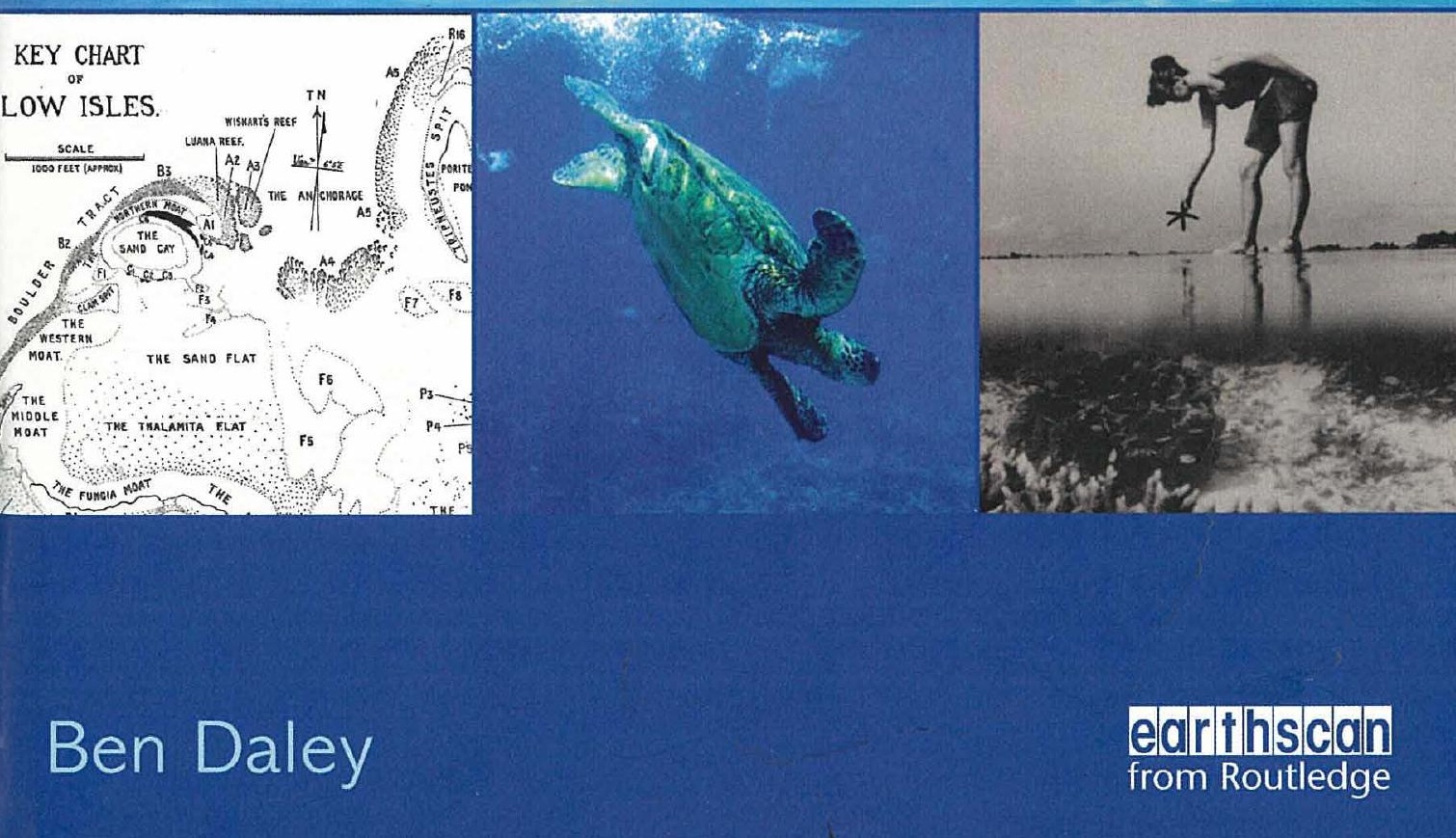




\section{The Great Barrier Reef}

The Great Barrier Reef is located along the coast of Queensland in north-east Australia and is the world's largest coral reef ecosystem. Designated a World Heritage Area, it has been subject to increasing pressures from tourism, fishing, pollution and climate change, and is now protected as a marine park. This book provides an original account of the environmental history of the Great Barrier Reef, based on extensive archival and oral history research.

It documents and explains the main human impacts on the Great Barrier Reef since European settlement in the region, focusing particularly on the century from 1860 to 1960 which has not previously been fully documented, yet which was a period of unprecedented exploitation of the ecosystem and its resources. The book describes the main changes in coral reefs, islands and marine wildlife that resulted from those impacts.

In more recent decades, human impacts on the Great Barrier Reef have spread, accelerated and intensified, with implications for current management and conservation practices. There is now better scientific understanding of the threats faced by the ecosystem. Yet these modern challenges occur against a background of historical levels of exploitation that is little-known, and that has reduced the ecosystem's resilience. The author provides a compelling narrative of how one of the world's most iconic and vulnerable ecosystems has been exploited and degraded, but also how some early conservation practices emerged.

Ben Daley is Lecturer in Environmental Management in the Centre for Development, Environment and Policy at the School of Oriental and African Studies (SOAS), University of London, UK. He was previously a researcher at the School of Earth and Environmental Sciences, James Cook University, Australia. 


\section{Earthscan Oceans}

\section{Governing Marine Protected Areas}

Resilience through diversity

Peter J.S. Jones

\section{Marine Policy}

An introduction to governance and international law of the oceans

Mark Zacharias

\section{The Great Barrier Reef}

An environmental history

Ben Daley

\section{Marine Biodiversity Conservation}

A practical approach

Keith Hiscock

For further details please visit the series page on the Routledge website: http://www.routledge.com/books/series/ECOCE 


\section{The Great Barrier Reef}

An environmental history

Ben Daley

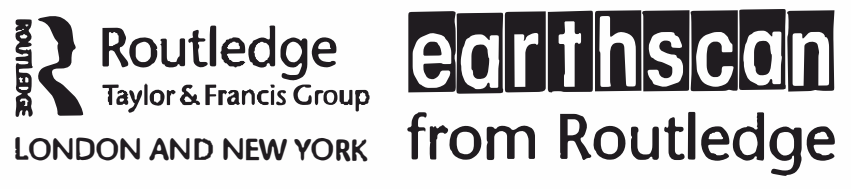


First published 2014

by Routledge

2 Park Square, Milton Park, Abingdon, Oxon OX14 4RN

and by Routledge

711 Third Avenue, New York, NY 10017

Routledge is an imprint of the Taylor $\mathscr{B}$ Francis Group, an informa business

(C) 2014 Ben Daley

The right of Ben Daley to be identified as author of this work has been asserted by him in accordance with sections 77 and 78 of the Copyright, Designs and Patents Act 1988.

All rights reserved. No part of this book may be reprinted or reproduced or utilised in any form or by any electronic, mechanical, or other means, now known or hereafter invented, including photocopying and recording, or in any information storage or retrieval system, without permission in writing from the publishers.

Trademark notice: Product or corporate names may be trademarks or registered trademarks, and are used only for identification and explanation without intent to infringe.

British Library Cataloguing-in-Publication Data

A catalogue record for this book is available from the British Library

Library of Congress Cataloging-in-Publication Data

Daley, Ben.

The Great Barrier Reef : an environmental history / Ben Daley. pages $\mathrm{cm}$. - (Earthscan oceans)

Includes bibliographical references and index.

1. Great Barrier Reef (Qld.) 2. Coral reef ecology - Australia -

Great Barrier Reef (Qld.) 3. Coral reefs and islands - Australia.

I. Title.

QE566.G7D35 2014

$578.77 \cdot 89476-$ dc23

2014005387

ISBN: 978-0-415-82439-2 (hbk)

ISBN: 978-0-203-54592-8 (ebk)

Typeset in Goudy

by HWA Text and Data Management, London

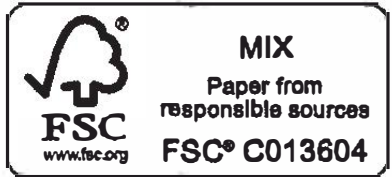

Printed and bound by CPI Group (UK) Ltd, Croydon, CR0 4YY 


\section{Contents}

List of figures

List of tables

vii

Foreword

ix

Acknowledgements

$x$

List of abbreviations

xii

xiii

1 Introduction

2 Reconstructing changes in the Great Barrier Reef

3 The natural context of changes in the Great Barrier Reef

4 The spread of European settlement in coastal Queensland

5 The bêche-de-mer, pearl-shell and trochus fisheries

6 Impacts on marine turtles

7 Impacts on dugongs

8 Impacts on whales, sharks and fish

9 The impacts of coral and shell collecting

10 The impacts of guano and rock phosphate mining 
vi Contents

12 Other impacts on coral reefs 184

13 Changes in island biota 201

14 Conclusion 224

References 229

Index 246 


\section{Figures}

1.1 The geographical extent of the Great Barrier Reef

1.2 The Great Barrier Reef World Heritage Area (GBRWHA) and the Great Barrier Reef Catchment Area (GBRCA)

4.1 (a) Area of sugar cane grown in Queensland, 1864-1988;

(b) Fertiliser application in the Great Barrier Reef Catchment Area (GBRCA), 1900-1980

5.1 (a) Weights and (b) values of bêche-de-mer harvested in Queensland, 1880-1889

5.2 Values of bêche-de-mer harvested in Queensland, 1901-1940 60

5.3 A bêche-de-mer lugger near Green Island, c.1931 61

5.4 The collection of pearl-shell aboard a Queensland lugger 63

5.5 (a) Weights of pearl-shell harvested in Queensland, 1890-1940;

(b) Values of pearl-shell harvested in Queensland, 1890-1940 67

6.1 Exports of tortoise-shell from Queensland, 1871-1938 74

6.2 Numbers of tortoise-shelling vessels registered in Queensland, 1895-1906

6.3 Exports of turtles from Queensland, 1867-1902

6.4 Loading a green turtle onto a boat using a winch, near Masthead Island, 1900s

6.5 Numbers of green turtles harvested in the Capricorn-Bunker Group, 1925-1949

6.6 A turtle-fishing party on the Fitzroy River, c.1930 82

6.7 Turtle-riding at Masthead Island, 1900s 84

6.8 Flatback turtles overturned on a resort island beach, 1900s 85

6.9 Turtle-riding at Heron Island, c.1930 85

7.1 Locations of individual dugong fisheries in Queensland, 1840-1970 97

7.2 Periods of operation of individual dugong fisheries in Queensland, 1840-1970

7.3 Quantities of dugong oil exported from Queensland, 1870-1902 99

7.4 Numbers of dugongs caught in Moreton Bay, 1884-1938 104

7.5 Dugongs caught at Burrum Heads, c.1937 105

8.1 A whale captured in east Australian waters, 1950s 115 
8.2 A large stingray captured in the Great Barrier Reef, c.1930 123

9.1 Coral collecting at Masthead Island, c.1900 131

9.2 The first coral reefs and foreshores protected by legislation, in 1933133

9.3 Assorted coral displayed at the Green Island kiosk, c.1940 138

9.4 Tourists gathering coral specimens from Heron Island reef, c.1930 139

9.5 Display of Great Barrier Reef coral for the Qantas office in Tokyo, 1961

9.6 Coral collecting areas in the Great Barrier Reef, 1962-1969 141

9.7 Commercial coral collectors working at Double Island reef, c.1930 143

9.8 Giant clam shells at Orpheus Island, 1967

10.1 Guano and rock phosphate mining locations in the Great Barrier Reef

11.1 Church built from burnt coral at Kobbura outstation, Fitzroy Island, c.1900 166

11.2 Coral mining locations in the Great Barrier Reef, 1900-1940 167

11.3 The location of the coral mining operation at Snapper Island 169

11.4 Letter and sketch map showing Averkoff's coral mining site at Alexandra Reef, 1929

11.5 Sketch map accompanying Sanders' application to mine coral from Sudbury Cay, 1930

11.6 Sketch map showing Garner's application to mine coral from Kings Reef No. 2 Area, 1937

11.7 Numbers of coral and shell-grit licences issued in Queensland between 1931 and 1968

11.8 The jetty at Upolu Cay used for loading material mined from the cay, c. 1933

11.9 Alexandra Reef, near Port Douglas, 2003

12.1 (a) The Heron Island reef before the construction of the boat channel, 1948; (b) the same reef after the construction of the boat channel, August 1971

12.2 The boat channel created at Lady Musgrave Island reef, $1966 \quad 187$

12.3 The access track for the lighthouse supply vessel at North Reef, 1960

12.4 A jetty constructed at Green Island, c.1956 193

12.5 The ten major island tourist resorts of the Great Barrier Reef, 1940195

12.6 Construction of the Hayman Island Resort, c.1962 198

13.1 (a) Numbers of coconut palms planted in the Great Barrier Reef, 1892-1900; (b) Coconut exports from Queensland, 1905-1911

13.2 The distribution of island coconut palm plantations in northern Queensland, 1898

13.3 The coconut palm plantation at Palm Island, c.1920 206

13.4 The airstrip at Lindeman Island, October 1963 


\section{Tables}

2.1 Some documentary sources relating to the Great Barrier Reef

2.2 Some visual representations relating to the Great Barrier Reef

2.3 Some oral sources relating to the Great Barrier Reef

3.1 Main types of coral reef classified by geomorphological characteristics

5.1 Species and values of bêche-de-mer harvested in Queensland, $1890 \quad 56$

6.1 The IUCN Red List status of the marine turtle species of the GBRWHA 


\section{Foreword}

The Great Barrier Reef, the largest coral reef ecosystem on earth, gained World Heritage listing in 1981 as 'the most impressive marine area in the world'. At the time of inscription, the IUCN evaluation stated '... if only one coral reef site in the world were to be chosen for the World Heritage List, the Great Barrier Reef is the site to be chosen'.

Since then, the Great Barrier Reef has been recognised as one of the best managed marine areas in the world. The 2004 Zoning Plan for the Great Barrier Reef Marine Park increased the proportion of the Marine Park that was highly protected by 'no-take' zones from less than 5 per cent to more than 33 per cent. This rezoning protected representative examples of each of the Reef's 70 bioregions (broad habitat types) occurring across its entire area of some $340,000 \mathrm{~km}^{2}$ including the surrounding waters.

This rezoning was hailed as a new benchmark in the systematic conservation planning of marine protected areas - an example of international best practice. It won numerous national and international awards.

Nonetheless, scientific information has now established that the Great Barrier Reef has been in serious decline for decades. The causes of the decline are well known: pollution from coastal development and agricultural runoff, extreme weather events and the impacts of climate change, particularly increasing temperature and ocean acidification.

The World Heritage Committee considered the state of conservation of the Great Barrier Reef World Heritage Area in 2012, and noted with concern a critical report from the World Heritage Centre/IUCN reactive monitoring mission that visited Australia earlier that year. UNESCO is scheduled to make a decision about whether to inscribe the Great Barrier Reef on the List of World Heritage in Danger at the time of writing in 2014.

Global concerns about the future of coral reefs increasingly and appropriately focus on climate change. Nonetheless, it is important to remember that the Great Barrier Reef ecosystem abuts the eastern coast of Queensland over some 14 degrees of latitude. Land modification associated with the increased human population, urban development and agricultural expansion in the Great Barrier Reef catchment area has reduced the quality of water flowing into the Great 
Barrier Reef lagoon. This area comprises some 25 per cent of the land area of Queensland, and is home to more than one million people in addition to the two million tourists that visit the region each year.

This book shows that the adverse impacts of coastal development and primary industries on the integrity of the Great Barrier Reef ecosystem have their genesis in the development of Queensland since European colonisation in the nineteenth century. Through a meticulous analysis of archival materials, official sources, publications, photographs and oral history evidence, this book documents for the first time how the colonisation of Queensland and the resultant growth of primary industries have contributed to the decline of the Great Barrier Reef. These primary industries have variously included: fisheries for bêche-de-mer, clam, coral, dugong, finfish, pearl-shell, prawns, sharks, shell-collecting, trochus, turtle and whales; mining for coral, guano and rock-phosphate; as well as agriculture, including the sugar cane and beef industries. Although most of the Great Barrier Reef islands are now protected as national parks, many islands were impacted by mining, the creation of coconut palm plantations, vegetation clearance, overgrazing by goats and the introduction of exotic vegetation.

Clearly marine park zoning alone is not enough to save the Great Barrier Reef, despite current zoning being world's best practice. This book provides important historical evidence that demonstrates that the detrimental impacts of increased human population, urban development and agricultural expansion in the Great Barrier Reef catchment area will have to be ameliorated to increase the resilience of the Great Barrier Reef World Heritage Area to the ravages of climate change.

Professor Helene Marsh

Distinguished Professor of Environmental Science

James Cook University

Townsville, Australia

June, 2014 


\section{Acknowledgements}

I am very grateful for the support, advice, encouragement and assistance given by my PhD supervisors, Dr Peter Griggs and Professor Helene Marsh, both at the School of Earth and Environmental Sciences, James Cook University, Australia. Their insights and expertise in this subject continue to guide me. I am also grateful for the contribution made by Dr David Wachenfeld of the Great Barrier Reef Marine Park Authority (GBRMPA). The research was funded by an Australian Postgraduate Award (Industry) of the Australian Research Council, with additional support from GBRMPA and James Cook University. I have also received funding for this research from SOAS, University of London, where I am currently based, as well as encouragement from my colleagues in the Centre for Development, Environment and Policy. I thank these individuals and organisations for their support.

Many individuals have contributed data or technical advice to my research. I am particularly grateful to the anonymous oral history informants who participated in qualitative interviews. I also thank those individuals who suggested informants, provided materials, corrected some of my errors and misunderstandings, or otherwise contributed to the research. In particular, staff of the Australian Museum, Bowen Historical Society, Cairns Historical Society, Fryer Library, GBRMPA Library, James Cook University Library, John Oxley Library, Mitchell Library, National Library of Australia, Queensland Museum, Queensland State Archives, State Library of Queensland and University of Queensland Library provided assistance in locating documents, photographs and oral history materials.

I am grateful for the kindness and support given by the Archdeacon family, Leah Talbot, Patrick Cooke, Melissa Nursey-Bray, Debra Stoter, Robert Rutten, Tania Cobham, Andrew Bryant, Kate Hannon, Greta Galloway, Alan Webster, Christine Ritchie, Lesley Newman, David Gillieson and Elaine Harding.

I am very grateful to Tim Hardwick and Ashley Wright at Routledge and Holly Knapp at HWA for their advice, encouragement and patience during the process of writing this book.

This book is dedicated to my family, with gratitude. 


\section{Abbreviations, acronyms and measurements}

\section{Abbreviations and acronyms}

ACRS Australian Coral Reef Society

AGPS Australian Government Publishing Service

AIMS Australian Institute of Marine Science

ANFB Australian National Film Board

ANU Australian National University

A.U.S.N. Australasian Union Steam Navigation

CHS Cairns Historical Society

COTS Crown of Thorns Starfish

CRC Co-operative Research Centre

CSIRO Commonwealth Scientific and Industrial Research Organisation

FAO Food and Agriculture Organisation

GBR Great Barrier Reef

GBRC Great Barrier Reef Committee

GBRCA Great Barrier Reef Catchment Area

GBRMP Great Barrier Reef Marine Park

GBRMPA Great Barrier Reef Marine Park Authority

GBRWHA Great Barrier Reef World Heritage Area

IIB Island Industries Board

IUCN International Union for Conservation of Nature

JCU James Cook University

JOL John Oxley Library

MCMC Mossman Central Mill Company

NADC Northern Australia Development Committee

NLA National Library of Australia

NPA National Parks Association of Queensland

NQNC North Queensland Naturalists' Club

$\mathrm{OHC} \quad$ Oral History Cassette

QBSES Queensland Bureau of Sugar Experimental Stations

QDAIA Queensland Department of Aboriginal and Islander Affairs

QDAS Queensland Department of Agriculture and Stock 


$\begin{array}{ll}\text { QDHM } & \text { Queensland Department of Harbours and Marine } \\ \text { QDNA } & \text { Queensland Department of Native Affairs } \\ \text { QDPI } & \text { Queensland Department of Primary Industries } \\ \text { QEPA } & \text { Queensland Environmental Protection Agency } \\ \text { QGITB } & \text { Queensland Government Intelligence and Tourist Bureau } \\ \text { QGTB } & \text { Queensland Government Tourist Bureau } \\ \text { QNPWS } & \text { Queensland National Parks and Wildlife Service } \\ \text { QPD } & \text { Queensland Parliamentary Debates } \\ \text { QPP } & \text { Queensland Parliamentary Papers } \\ \text { QPWS } & \text { Queensland Parks and Wildlife Service } \\ \text { QSA } & \text { Queensland State Archives } \\ \text { QSPCA } & \text { Queensland Society for the Prevention of Cruelty to Animals } \\ \text { QVP } & \text { Queensland Votes and Proceedings } \\ \text { SCQ } & \text { Statistics of the Colony of Queensland } \\ \text { SLNSW } & \text { State Library of New South Wales } \\ \text { SLQ } & \text { State Library of Queensland } \\ \text { SPCK } & \text { Society for the Promotion of Christian Knowledge } \\ \text { SSQ } & \text { Statistics of the State of Queensland } \\ \text { SST } & \text { Sea surface temperature } \\ \text { UNEP } & \text { United Nations Environment Program } \\ \text { UNESCO } & \text { United Nations Educational, Scientific and Cultural Organization } \\ \text { UQ } & \text { University of Queensland } \\ \text { WTWHA } & \text { Wet Tropics World Heritage Area }\end{array}$

\section{Measurements}

Where used in the text, measurements have been cited as they appear in the original source. The following conversion factors may be used:

\section{Weight and volume}

1 ton $=20 \mathrm{cwt}$ (approximately $1,016 \mathrm{~kg}$ )

$1 \mathrm{cwt}$ (hundredweight) $=112 \mathrm{lb}$ (approximately $51 \mathrm{~kg}$ )

1 qtr (quarter) $=28 \mathrm{lb}$ (approximately $13 \mathrm{~kg}$ )

$1 \mathrm{lb}$ (imperial pound) $=16 \mathrm{oz}$ (approximately $0.5 \mathrm{~kg}$ )

$1 \mathrm{oz}$ (ounce) = approximately $30 \mathrm{~g}$

1 gal $($ imperial gallon $)=$ approximately 4.5 litres

\section{Length, depth and area}

$1 \mathrm{ft}$ (foot) $=12$ inches (approximately $0.3 \mathrm{~m}$ )

1 in (inch) $=$ approximately $2.5 \mathrm{~cm}$

1 fathom = approximately $1.8 \mathrm{~m}$

1 hectare $=10,000$ square metres 


\section{Monetary values}

Monetary values are stated as they appear in the original sources and no conversion factors have been applied. The following symbols denote imperial currency values:

$£ 1$ (imperial pound) $=20 \mathrm{~s}$

$1 \mathrm{~s}$ (imperial shilling) $=12 \mathrm{~d}$ (imperial pence)

$1 \mathrm{~d}$ (imperial penny)

Those units were used in Australia until 14 February 1966, when the imperial currency was replaced with the modern, decimal system of dollars and cents. In this book, the modern symbol (\$) refers to the Australian dollar. In 1966, following decimalisation, a conversion for the Australian dollar (in relation to the imperial pound) was $£ 1=$ approximately $\$ 2.50$. 



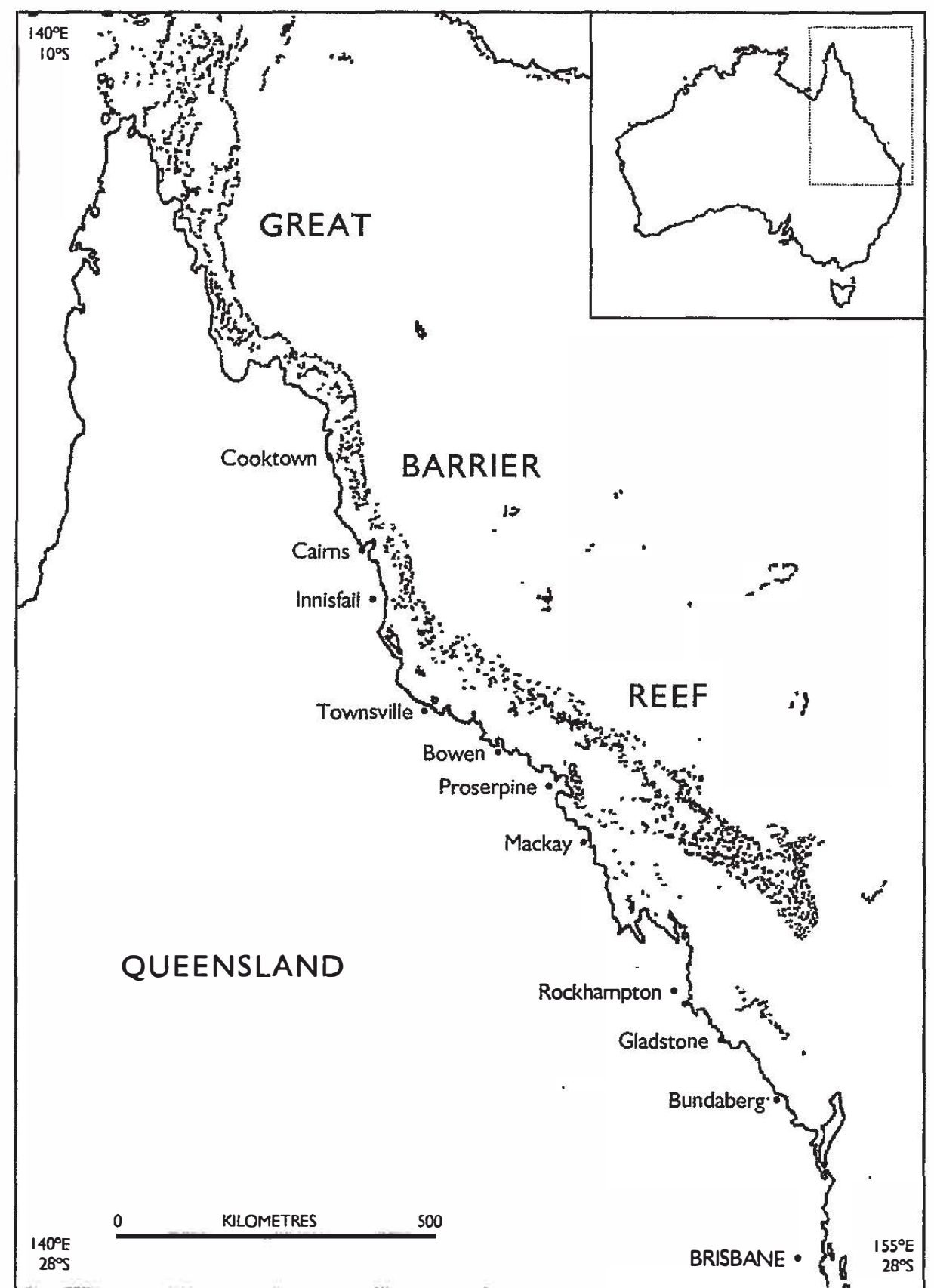

Figure 1.1 The geographical extent of the Great Barrier Reef. Source: Author, adapted from Wachenfeld et al. (1997, p4)

The Great Barrier Reef is a large, complex, dynamic entity that is difficult to define precisely. It has been defined in various ways since Matthew Flinders first used the term 'Great Barrier Reef' in 1802 (Bowen and Bowen, 2002); Maxwell (1968) listed several of those definitions in his Atlas of the Great Barrier Reef. The term 'Great Barrier Reef Province' refers to the coral reefs of eastern Australia and Torres Strait, one of seven coral reef provinces in the south-western Pacific Ocean. The 'Great Barrier Reef Region' describes the large coral reef area that was initially designated for protection under Australian law; in 1975, that term was replaced by the GBRMP, which extends northwards as far as the latitude of 


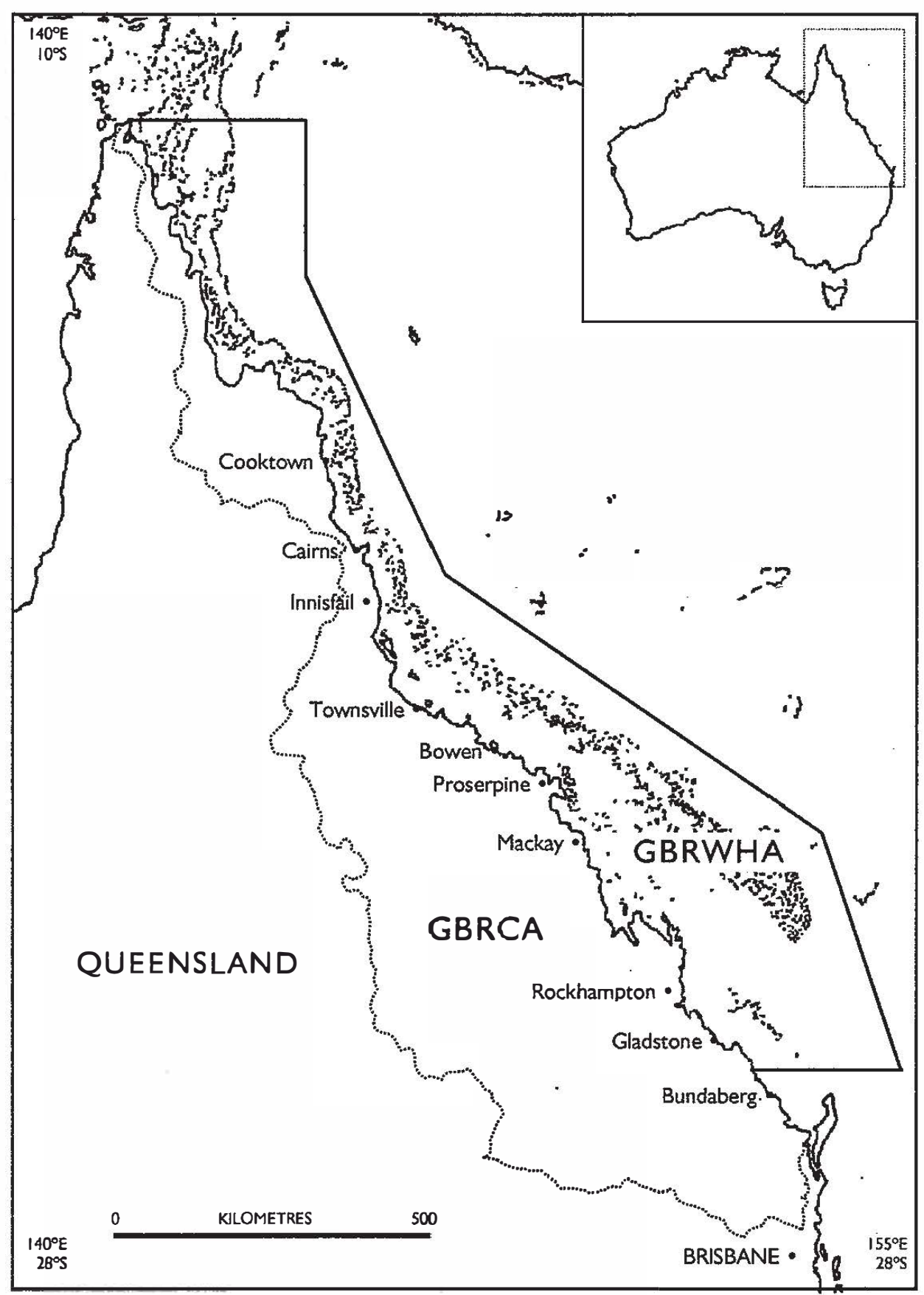

Figure 1.2 The Great Barrier Reef World Heritage Area (GBRWHA) and the Great Barrier Reef Catchment Area (GBRCA). Source: Author, adapted from Wachenfeld et al. (1997, p4); Furnas (2003, p2); GBRMPA (2009)

Cape York but excludes the coral reefs of Torres Strait. The GBRWHA occupies approximately the same area as the GBRMP, although some variations exist in their coastal boundaries: the GBRWHA also includes the islands of the Great Barrier Reef, while the GBRMP consists of the marine environment alone (Lucas et al., 1997, pp36-7, 99). All of these terms are found in the scientific literature of the Great Barrier Reef, reflecting the problem of adequately describing the boundaries of this ecosystem. Yet most historical sources predate the definitions of the GBRMP and the GBRWHA, and many simply use the general term 'Great 
Barrier Reef'. In this book, a broad definition of the Great Barrier Reef is used, one that encompasses the GBRWHA (including its islands) and the adjacent areas of Torres Strait, Hervey Bay and Moreton Bay, since some important historical changes occurred in each of those parts of the ecosystem.

Conceptions of the Great Barrier Reef held by Indigenous Australians can differ significantly from those of non-Indigenous Australians. Many Indigenous Australians regard the Great Barrier Reef as part of traditional 'sea country'; some also regard it as a sacred place whose importance is reflected in creation stories. Some marine animals found in the Great Barrier Reef, including dugongs and marine turtles, have formed a vital part of the social practices and cultural identities of some coastal Indigenous Australian communities. Given the significance of this ecosystem for biodiversity conservation, human use of the GBRWHA now raises important questions about self-determination, participation and co-management of coastal and marine resources by Indigenous Australians. Recently, scholars using postcolonial approaches (amongst others) have produced new interpretations of colonisation in Australia, developed better narratives of contact and resistance, and highlighted the need for more inclusive accounts of environmental history, particularly for settler societies. Their insights suggest that accounts of the environmental history of the Great Barrier Reef that exclude Indigenous Australian perspectives are, at best, partial and incomplete (Loos, 1982; Smyth, 1994; Jacobs, 1996; Reynolds, 2003).

However the Great Barrier Reef is defined, the ecosystem does not exist in isolation: it is closely interconnected with its adjacent environments. In particular, the GBRWHA is strongly influenced by its sources of freshwater, sediments and nutrients, especially the 35 drainage basins of eastern Queensland that form the Great Barrier Reef Catchment Area (GBRCA) (Figure 1.2). The GBRCA includes around 25 per cent of the land area of Queensland, and runoff from that area represents a major input to the GBRWHA. Therefore, the GBRWHA and the GBRCA form an interconnected unit: environmental changes in the GBRWHA may be closely related to both human activities and environmental changes in the GBRCA (Furnas, 2003). Significant land uses in the GBRCA include rangeland cattle grazing, forestry, sugar cane farming, cultivation of bananas and other tropical fruits, aquaculture and mining. In addition, rapid urban development has occurred in parts of coastal Queensland, and over one million people now live in the GBRCA. Economic development in coastal Queensland has also been significant, including the growth of the commercial fishing, shipping and tourism industries in the GBRWHA, with tourism now attracting around two million visitors per year. The cumulative effects of all of those activities - in both the GBRCA and the GBRWHA - have prompted concerns about the extent to which they have contributed to the large-scale degradation of the Great Barrier Reef, particularly its nearshore habitats. 


\section{The decline of the Great Barrier Reef}

Concerns about the condition of the Great Barrier Reef (and of other coral reefs worldwide) increasingly focus on the global-scale threats to these ecosystems presented by climate change, especially the effects of coral bleaching, ocean acidification and sea-level rise. Such concerns are acute since it is now recognised that, under conditions expected to occur in the twenty-first century, global warming and ocean acidification will compromise the ability of corals to form robust carbonate skeletons, with the result that coral reef ecosystems are expected to become less diverse and to have reduced capacity to maintain carbonate reef structures (Hoegh-Guldberg et al., 2007, p1737). In addition, those broad-scale changes are likely to interact synergistically with other impacts, exacerbating the effects of water pollution and disease, and thereby forcing coral reefs closer towards thresholds for functional collapse. Consequently, rapid climate change in conjunction with a range of other impacts is expected to lead to the widespread degradation and destruction of corals and coral reefs worldwide, with serious implications for tourism, reef-associated fisheries, coastal protection and human communities dependent upon reef resources (Hoegh-Guldberg, 1999; Lough, 1999; Hoegh-Guldberg et al., 2007; Veron, 2009). Within that broader context, the resilience of coral reef ecosystems to the effects of climate change could be enhanced if other (regional and local) environmental stresses are minimised. From this perspective, it becomes important to characterise and understand the extent to which the Great Barrier Reef is - and has already been - affected by those other environmental stresses, including historical ones.

Although the current, global-scale threats to coral reef ecosystems - especially those due to climate change - are formidable ones, the deterioration of coral reefs may have commenced much earlier than those threats were first recognised. Many reports suggest that the condition of the Great Barrier Reef has declined since European settlement commenced in Queensland, as a result of direct exploitation and the development of adjacent coastal land. In particular, the terrestrial runoff of sediments, nutrients and other pollutants has probably caused a substantial deterioration of water quality in parts of the Great Barrier Reef, and those effects - together with the over-exploitation of reef resources - have significantly degraded some nearshore coral reefs and seagrass communities. The Queensland Environmental Protection Agency (QEPA, 1999, p5.4) reported that nutrient inputs to the Great Barrier Reef lagoon have increased substantially over the decadal timescale due to extensive land clearing, catchment development and coastal runoff, and that the relatively enclosed and shallow nature of the lagoon makes it relatively susceptible to the effects of eutrophication and deteriorating water quality. Williams (2001, pp3-4) argued that sediment discharges have increased by three or four times, nitrogen discharges have doubled and phosphorus quantities have increased by six to ten times since 1800; as a result, the impacts of terrestrial runoff of nutrients and sediments on coastal parts of the GBRWHA - due to both past and current land use practices - have become a 
significant cause for concern. The impacts of coastal runoff are most significant for nearshore reefs and seagrass beds within 20 kilometres of the coast, with the most severely impacted areas lying between Port Douglas and Hinchinbrook Island, and between Bowen and Mackay (Williams et al., 2002, p1).

The Commonwealth of Australia Productivity Commission (2003, pp xxviii, 37, 42) has acknowledged evidence of an increase in sediment and nutrients entering the Great Barrier Reef lagoon since European settlement, due to the runoff of sediments, nutrients and chemicals from agricultural and pastoral land, especially as a result of cattle grazing and crop production. This has led to the decline of corals, seagrass communities and fish populations. The Great Barrier Reef Protection Interdepartmental Committee Science Panel (2003, pp2, 9, 12-13) also found evidence of accelerated erosion and a large increase in the delivery of nutrients to the Great Barrier Reef over pre-1850 levels, with consequent disturbance of the ecological function of inshore coral reefs. The report stated that some areas of the Great Barrier Reef - those most affected by terrestrial runoff - now appear to be degraded and/or slow to recover from natural disturbances such as tropical cyclones. In addition to the effects of deteriorating water quality, the degradation of the Great Barrier Reef has also occurred due to the over-exploitation of reef organisms, leading to the depletion of resources at Langford, Heron, North West, Tryon and Lady Musgrave reefs, and near Dingo, Four Mile and Kurrimine Beaches (QEPA, 1999, p5.13). Particular damage has been caused by commercial and recreational shell collecting, commercial coral collecting, aquarium fish collecting and bêche-de-mer (trepang or sea cucumber) collecting (QEPA, 1999, p5.27).

Besides these scientific and official reports, many anecdotal reports of a decline in the Great Barrier Reef have been made, attributing the degradation of coral reefs and other parts of the ecosystem to a multitude of human impacts: shipping, dredging, coastal and marine pollution, sediment and nutrient runoff, habitat destruction, coastal development, fishing, tourism and the collection of marine specimens (Lucas et al., 1997, pp65-6). The degradation of the Great Barrier Reef is considered by some observers to have occurred - or to have accelerated - in living memory. The most severe degradation is thought to have affected the nearshore habitats in the most accessible parts of the ecosystem: in the Cairns, Townsville and Whitsunday regions, which have experienced intensive human use and substantial terrestrial runoff. Given the immense ecological, economic and social importance of the Great Barrier Reef, there has been considerable scientific and public interest in either confirming or refuting those anecdotal reports of decline in the ecosystem. Furthermore, establishing the extent to which the Great Barrier Reef has changed since European settlement is important to inform the effective management of the ecosystem. However, extensive, systematic, scientific monitoring of the Great Barrier Reef commenced only around 1970, and scarce scientific data exist for the earlier period. Consequently, anecdotal claims that the ecosystem has deteriorated - especially prior to 1970 are difficult to assess using existing scientific baselines. 


\section{Aims and approaches}

In an attempt to evaluate anecdotal reports of a decline in the condition of the Great Barrier Reef for the period before extensive scientific monitoring began - especially prior to 1970 - my research used an array of qualitative methods and sources to reconstruct the environmental history of the Great Barrier Reef. Specifically, my research documents the main changes that have occurred in the coral reefs, islands and marine wildlife of the ecosystem. Many qualitative sources, including documentary and oral history materials, provide indications of the condition of the Great Barrier Reef at specific locations and at various times in the past. Archival and oral history sources, in particular, have been little used to investigate changes in the coral reefs, islands and marine wildlife of the ecosystem. A wide range of documentary materials was collected from Australian and UK archives, libraries, museums and historical societies. Those sources were used to complement and cross-reference a variety of oral history materials (both pre-existing and original): in particular, semi-structured, qualitative interviewing was used to collect new oral history evidence from informants who had observed human activities and environmental changes in the Great Barrier Reef. In addition to presenting an environmental history narrative of some of the main changes in the Great Barrier Reef since European settlement, I also evaluated the potential for qualitative methods to inform research into coastal and marine environmental history.

Coastal and marine environmental histories are not abundant in the scholarly literature, and environmental histories of coral reef ecosystems are very rare. Within the academic sub-discipline of environmental history, Australian studies comprise only a small subset, and most of those focus on the terrestrial themes of forests, soils and agriculture. There is a strong geographical bias in the literature of Australian environmental history in favour of environments in south-eastern Australia, whilst other areas have been comparatively neglected. Environmental histories of the Great Barrier Reef are very scarce: two notable works have been produced, by Bowen (1994) and by Bowen and Bowen (2002), but those focus principally on the history of exploration, environmental policy and management in relation to the Great Barrier Reef rather than on specific changes in the coral reefs and associated habitats of the ecosystem per se. Moreover, whilst Bowen and Bowen (2002) made extensive use of documentary materials, there is scope for a new account based on the analysis of archival sources - including some recently-available records of the former Queensland Department of Native Affairs (QDNA) - and on original oral history evidence.

Conceptual, theoretical and philosophical questions about environmental history have generated considerable debate among practitioners, and the field is characterised by a broad diversity of methods and approaches. One particularly inclusive approach is Cronon's (1992) narrative approach, which considers the task of environmental history to be, above all, the production of narratives, and which acknowledges the central role of a narrator in telling a convincing story about environmental change. Such an approach acknowledges that perceptions 
of environmental change reflect the diverse views of individuals in specific communities; it is therefore well suited to the collection and interpretation of qualitative materials, including the archival records of government departments and the (equally) value-laden, interpretive nature of oral history sources. In its methodology, my research was informed by the approach of Denzin and Lincoln (2000, p3), who defined qualitative research simply as 'a situated activity that locates the observer in the world'. Those authors argued that qualitative research is a distinct field of academic inquiry that is concerned with the interpretation of empirical materials in order to produce representations, such as recordings and texts; consequently, the outcome of qualitative research is itself an interpretation of reality. Like Cronon's (1992) narrative approach to environmental history, Denzin and Lincoln's (2000) approach to qualitative research emphasises the pivotal position of the researcher, whose values and attitudes fundamentally influence the research process. Therefore, those two approaches are complementary: each uses postmodern critical theory, examines the role of the narrator/researcher and emphasises the social and political contexts of representation.

Some environmental historians have emphasised the importance of reconstructing past environments in order to derive baselines that can be used to assess environmental change (Dovers, 1994; Gammage, 1994). Such reconstructions of the baseline condition of the Great Barrier Reef at the time of European settlement - if those were possible to produce - could reveal subsequent changes in the coral reefs and associated habitats of the ecosystem. Some researchers have attempted to establish this type of baseline using historical sources: Wachenfeld $(1995,1997)$, for example, compared historical photographs of known coral reef areas in the Great Barrier Reef with modern images, although he acknowledged that multiple methodological difficulties limit the value of that technique in reconstructing changes in coral reefs. In general, any attempt to reconstruct ecological baselines for the Great Barrier Reef is problematic, for several reasons: (a) the historical records about the ecosystem are discontinuous and extremely patchy; (b) only limited scientific monitoring of the Great Barrier Reef took place before around 1970; and (c) coral reefs are highly dynamic systems, both spatially and temporally, across a very wide range of scales. The last of these considerations has prompted some to suggest that any attempt to establish a baseline for coral reef ecosystems may be futile. Veron (2009, p36, emphasis in original), for instance, has stated that the condition of coral reefs can never be regarded as permanent, 'for there are no baselines for coral reefs, only intervals of time over which the environment appears not to change'. Moreover, attempts to reconstruct ecological baselines are also challenged by the postmodern view that all representations of reality are interpretive and value-laden: they do not record objective realities. Therefore, any narrative of environmental changes in the Great Barrier Reef is not definitive but represents only one of many possible readings of the historical evidence.

Although it may be impossible to reconstruct, definitively, the pre-European state of the Great Barrier Reef and the environmental changes that have occurred 
subsequently, it is nevertheless possible to write an environmental history narrative of changes in this ecosystem; for, as Dovers $(1994, \mathrm{p} 4)$ has argued, there are 'good stories' to be told about the ways in which humans have interacted with their environment. The collection of evidence from documentary sources and oral histories of the Great Barrier Reef is valuable because, taken together, this evidence forms the basis of a 'convincing non-fiction' about the Great Barrier Reef that includes the perspectives of coral collectors, shell collectors, boat operators, fishers, farmers, divers, scientists, environmental managers, government officials, conservationists and naturalists, among many others (Cronon, 1992, p1373). Despite postmodern claims about the impossibility of reconstructing past environments, such an environmental history is necessary in order to provide rich, contextual descriptions of changes in the Great Barrier Reef. My account attempts to locate human activities within a context of changing environmental conditions, to allow an evaluation of human impacts to be made and to illuminate some key aspects of the changing relationship between humans, their activities and the Great Barrier Reef. In addition, in evaluating the potential for qualitative sources to inform environmental history research into an ecosystem of immense scientific interest and importance, this research has inevitably crossed disciplinary boundaries (Powell, 1996; Dovers, 2000). Interdisciplinary work of this kind can potentially offer fresh insights into the changing relationship between humans and the Great Barrier Reef since European settlement, and into the consequent environmental changes.

\section{Scope and limitations}

As an environmental history narrative, this account is concerned principally with the changing relationship between humans, their activities and the Great Barrier Reef for the historical period, which in this case is primarily the period since around 1860, when the spread of European settlement in coastal Queensland commenced. (However, some earlier European exploitation of resources in the Great Barrier Reef - such as bêche-de-mer fishing - had already occurred by that year.) The narrative focuses on the period until around 1960, after which an increasing body of scientific literature documenting changes in the Great Barrier Reef emerged. In general, therefore, the narrative presented here spans roughly a single century (1860-1960) of unprecedented changes in the ways in which humans encountered, experienced and exploited the Great Barrier Reef. There is some justification for focusing on this particular century of change in the ecosystem: it is a period for which scant scientific data have been collected, yet it was the century during which the most intensive exploitation of the Great Barrier Reef has ever occurred. Many historical industries operated in the region during that time - often with minimal, if any, regulation - and significant transformations of some parts of the Great Barrier Reef occurred. However, in some places, for some particular themes, and where especially informative sources were available, the narrative extends beyond that timeframe (both earlier and 
later). For instance, the construction of the navigation beacon on Raine Island in 1844 is included in this account, as it represents a significant (if localised) impact on one part of the Great Barrier Reef.

In general, my research focused on the area bounded by the GBRWHA, as this provided convenient limits to an extensive ecosystem that crosses administrative boundaries and that is difficult to define otherwise (Figure 1.2) However, such a definition is inevitably artificial: the GBRWHA is a recent invention. Some environmental impacts on the Great Barrier Reef derive from outside the GBRWHA, and many marine animals regularly cross its boundaries. Therefore, this research belongs within a larger geographical context. In some cases, especially where changes in marine wildlife were concerned, I used materials that related not only to the GBRWHA but that also covered the adjacent areas of Torres Strait (to the north) and Hervey and Moreton Bays (to the south). The use of such materials is justified because some large marine animals, including humpback whales, dugongs and marine turtles, range across the boundaries of the GBRWHA, and impacts have been sustained by these animals both inside and outside of those boundaries. Some early European reef fisheries, including the beche-de-mer and pearl-shell fisheries, also long predated and operated across the present boundaries of the GBRWHA.

Inevitably, the scope of my research was limited by the availability of suitable materials. Nevertheless, many of the available archival materials, official reports and records of various government departments, historical books (particularly literature categorised in the 'Queensland travel and description' genre), historical photographs and oral histories (both pre-existing and original) were used extensively to obtain rich descriptions of human activities and their environmental impacts. In addition, some of the scientific reports produced as a result of the various geological, biological and ecological expeditions to the Great Barrier Reef - including the papers of the 1928-1929 Great Barrier Reef Expedition to Low Isles - and the manuscripts of notable reef scientists such as Isobel Bennett were also consulted. Interpretation of those materials relied on the use of multiple sources wherever possible, to allow evidence to be crossreferenced and to reveal errors and biases. In particular, original oral histories were compared with documentary evidence, where possible, to explore the subjectivity of informants' observations and recollections.

The scope of my research was also limited by some pragmatic considerations. Environmental changes are difficult to define, especially in a vast, complex ecosystem that is characterised by almost constant change on a wide range of geographical and temporal scales. I adopted a general, working definition of environmental change as any alteration in the physical appearance of the coral reefs, islands or their associated habitats; that broad definition was chosen as it would include the types of environmental changes most likely to have been observed by oral history informants. In contrast to major physical changes, other changes in the Great Barrier Reef - such as biological or ecological changes were probably imperceptible to informants; nor are such changes likely to have 
been recorded reliably in documentary sources. Therefore, my research focuses on broad-scale, discrete, observable, physical changes in the Great Barrier Reef and neglects many other changes that may have occurred. Nonetheless, there can be little doubt that those human impacts that dominate this narrative constitute environmental changes; those activities represent the use of resources, and the modification of habitats, on an unprecedented scale in the Great Barrier Reef.

In addition to the limitations imposed by the scope of my research, several other limitations also require some explanation. My study was constrained by difficulties in obtaining suitable oral history evidence, particularly in recruiting informants who could recall visiting the Great Barrier Reef prior to the Second World War. Informants were most easily recruited in northern Queensland (particularly in the Cairns and Townsville areas), where the Great Barrier Reef lies in closer proximity to the mainland. The greater concentration of tourism activities in the Cairns, Townsville and Whitsunday areas also biased the geographical coverage of oral history evidence, for more informants encountered the Great Barrier Reef in those areas than elsewhere. Several periods of dedicated fieldwork were undertaken - including visits specifically to under-represented locations in central and southern Queensland - and telephone interviewing was also used, in an attempt to recruit informants from locations for which the oral history record was sparse.

Another limitation of my research is the uneven geographical coverage of the documentary sources describing the Great Barrier Reef. In particular, the Capricorn-Bunker Group of the Great Barrier Reef is comparatively welldocumented in historical books, leaflets, films and Queensland Government reports and records, reflecting the earlier popularity of the Capricorn-Bunker Group for tourism, scientific research and naturalism in comparison with the more remote, northern parts of the Great Barrier Reef. The relative scarcity of documents describing the northern region hindered the cross-referencing of sources for this area, as there were locations for which oral histories could not be supported by documentary sources and vice versa. However, the variability in geographical coverage of documentary materials underlines the fact that European access to, and uses of, the Great Barrier Reef varied markedly along the coast of Queensland; as a result, different parts of the Great Barrier Reef inevitably have different environmental histories.

My research also faced limitations relating to the use of archival materials. McLoughlin $(1999,2000)$ described some of the difficulties in using archival materials in environmental research, and I encountered similar problems in my research. For example, the sequence of archival files of the Queensland Department of Harbours and Marine (QDHM) relating to coral mining in the Great Barrier Reef begins and ends abruptly, with some obvious omissions; it is likely that other, similar files were lost when the departmental offices in Brisbane were inundated during the Australia Day floods of 27 January 1974. The administration of the Great Barrier Reef prior to the formation of the GBRMP was complex, involving six different Commonwealth and Queensland 
Government departments, as Bowen and Bowen (2002, p291) acknowledged, and the archival records of those various departments contain gaps and variations in their coverage. As a result of such limitations, this narrative is incomplete, and the evidence for some environmental changes is suggestive rather than conclusive. To some extent, oral history evidence could be used to fill gaps in the archival records.

A further, significant limitation of my research was the lack of an Indigenous Australian perspective towards changes in the Great Barrier Reef since European settlement, despite attempts to recruit informants from Aboriginal and Torres Strait Islander communities. Unfortunately, therefore, my environmental history does not represent Indigenous Australian perspectives towards the activities and impacts of European settlers in the Great Barrier Reef. Further research, incorporating Indigenous Australian perspectives, could provide an important, alternative perspective towards this subject. Consequently, my study contains a Eurocentric bias. I have not attempted to write a postcolonial account of Indigenous Australian resistance to European perceptions and uses of the Great Barrier Reef; nor did I attempt to investigate the ways in which Indigenous Australian interactions with the Great Barrier Reef were altered by European settlement, and with what economic, social, cultural and political consequences. Those areas of inquiry remain valuable directions for further research.

\section{Outline of this book}

The material that follows begins, in Chapter 2, with a more detailed account of the methods used in my research; the chapter outlines the sources of data available and the techniques of data collection and analysis used. It also contains a discussion of the particular issues involved in using archival materials and oral histories in my research. This is followed, in Chapter 3, by a brief overview of the natural-context of changes in the Great Barrier Reef. In particular, the importance of two natural processes is emphasised: the geomorphological evolution of the continental shelf during the Holocene, and the occurrence of tropical cyclones which frequently cause damage to coral reefs. The purpose of that brief account is to demonstrate that historical changes in the Great Barrier Reef occur against a background of ongoing degradation of coral reefs in this region. Further contextual material is presented in Chapter 4, which briefly outlines the historical context for my narrative: the spread of European settlement in coastal Queensland. The chapter describes the northward expansion of European settlement and economic activities in the region, which depended on safe navigation through Queensland coastal waters, as well as on the closer settlement that accompanied the spread of sugar cane farming. The expansion of sugar cane farming was accompanied by substantial environmental degradation, as Griggs $(2005,2006,2007,2011)$ has acknowledged, due to deforestation, soil erosion and swamp drainage, which led to enhanced sediment and nutrient runoff to the Great Barrier Reef. Commercial fisheries and tourism in the Great Barrier Reef, 
combined with rapid coastal development, have also contributed increasingly to human impacts on the ecosystem. Therefore, Chapter 4 shows that European settlement, sugar cane farming and coastal development in Queensland have been closely interconnected with changes in the Great Barrier Reef.

Subsequent chapters present the results of my research, arranged broadly by theme. The Great Barrier Reef is a vast region in which a multitude of human activities and impacts have occurred, over varying timescales. Moreover, those activities and impacts often overlapped, both temporally and geographically, and they are sometimes difficult to classify and categorise. Consequently, it is difficult to write a chronological account of these many activities and their impacts, which have instead been grouped roughly by theme (and are not strictly chronological). One group of chapters examines different forms of exploitation of living resources in the Great Barrier Reef. Chapter 5 describes the effects of the early European reef fisheries, which exploited bêche-de-mer, pearl-shell and trochus. Chapter 6 examines various human impacts on marine turtles, including those due to the tortoise-shell industry, the commercial turtle fisheries, the recreational activity of turtle-riding, a turtle farming initiative and Indigenous hunting of turtles. In Chapter 7, similar impacts on dugongs are considered: those due to commercial fishing, a scheme to supply dugong products to Indigenous settlements and Indigenous hunting of dugongs. Chapter 8 covers some of the impacts sustained by humpback whales, sharks and fish due to the operation of various fisheries in the region. In Chapter 9, the effects of over-collection of corals and shells are considered, a cumulative impact on those organisms that has been previously little-documented. That group of chapters is followed by two chapters focusing on the exploitation of non-living resources: the mining of guano and rock phosphate (in Chapter 10) and of coral and coral sand (in Chapter 11). (In the case of coral mining, however, the distinction between 'living' and 'non-living' resources is not always an accurate one, since both living and non-living coral was destroyed by coral mining.) Two further chapters consider a range of other ways in which the physical and ecological habitat of coral reefs and islands was degraded or destroyed, respectively: by the clearance of access tracks and channels, military target practice operations, reef-walking and infrastructure development (in Chapter 12), and through the modification of island vegetation and fauna (in Chapter 13). Finally, the book concludes with a brief consideration of the overall significance of these multiple, unprecedented impacts on the Great Barrier Reef (Chapter 14).

Taken together, this account provides evidence of sustained, extensive damage to some coral reefs, islands and organisms of the Great Barrier Reef as a result of the over-exploitation of resources and the degradation and destruction of habitats. There is unequivocal evidence that some parts of the Great Barrier Reef have experienced severe impacts - that have varied in their location and intensity - since European settlement. Consequently, although the Great Barrier Reef remains one of the best-protected coral reef ecosystems in the world, some of its habitats were far from pristine at the time of the formation of the GBRMP 
in 1975. At least partially as a result of human activities, some coral reef areas have been degraded to the extent that recovery to their former condition is now unlikely, and many other reef areas have been affected to a lesser extent. Similarly, there is abundant evidence that some islands of the Great Barrier Reef - particularly Raine, Green, Magnetic, Holbourne, North West, Heron, Fairfax, Lady Musgrave and Lady Elliot Islands - were subjected to considerable exploitation and had been significantly modified by the time of the formation of the GBRMP. In addition, some of the impacts sustained by marine wildlife species in the Great Barrier Reef have been severe and, whilst their ecological consequences are not always easy to establish, it is clear that the over-exploitation of some populations and species - sometimes over the decadal timescale - has substantially increased their mortality, morbidity and vulnerability to other environmental changes. Overall, the evidence presented in this book suggests that the Great Barrier Reef was exploited earlier, for a longer period, in more locations and more intensively than has previously been documented. That story - of the multiple and unprecedented uses of, and changes in, the Great Barrier Reef since European settlement - forms the main subject of my narrative. Above all, my account illustrates the damage that can be inflicted on coral reefs and their associated habitats and species in the absence of effective environmental management. 